\title{
PENERAPAN UANG MUKA DI CATERING AULIA DAN CATERING HJ. WATI PERSFEKTIF EKONOMI ISLAM DI KOTA PALANGKA RAYA
}

\author{
Muhammad Riza Hafizi ${ }^{1}$, Jelita ${ }^{2}$ dan Deanti Aulia ${ }^{3}$
}

\begin{abstract}
Catering becomes a solution to consumers who want to fulfill their needs and wants without having to waste time and energy. This is also a challenge for a catering businessman to maintain and keep improving their service quality from time by time so can keep satisfying consumers. In the payment system, catering business is using down payment system. According to that case, to understand more about how the down payment application in Islamic economics perspective need to studied more details. This research aimed to analyze and understand (1) How are the down payment application of Catering Aulia and Catering $\mathrm{Hj}$. Wati in Palangkaraya City. (2) How the buying and selling system with the down payment in Islamic economics perspective.

The result of this research is the application of down payment in Catering Aulia and Catering Hj. Wati is an 'urf or a habit that is done both for catering owners and their customers. Application of down payment in catering payments in terms of the usual materials included in the 'urf fi'li, while in terms of good and bad judgments included into 'urf shahih. In practice, both in Catering Aulia and Catering Hj. Wati the amount of down payment is not specified. And if there is an order cancellation then the down payment will be refunded in full except at certain moments. Implementation of down payment viewed in terms advantages may be done as long as no party feels disadvantaged. Down payment made to avoid any breach between the catering owners and consumers.
\end{abstract}

Keywords: down payment application, islamic economic perspective

\section{PENDAHULUAN}

\section{Latar Belakang Masalah}

Belakangan ini, berbagai macam bisnis mulai berkembang dengan pesat beriringan dengan semakin tingginya tingkat kebutuhan. Begitupula dengan bisnis pelayanan jasa catering yang merupakan salah satu bidang usaha boga. Bisnis catering ini berkembang pesat di Indonesia. Semakin meningkatnya kebutuhan, maka semakin membuka peluang-peluang bisnis yang dapat dimanfaatkan oleh masyarakat Indonesia dalam mendapatkan keuntungan, salah satunya adalah bisniscatering. Karena tingginya tingkat kebutuhan, usaha catering ini menjadi bisnis yang cukup menjanjikan.

Catering menjadi solusi bagi konsumen yang ingin memenuhi kebutuhan dan keinginannya tanpa harus membuang waktu dan tenaga. Hal ini juga merupakan tantangan bagi para pebisnis catering untuk dapat menjaga dan terus meningkatkan kualitas mutu pelayanannya dari waktu ke waktu sehingga dapat terus memuaskan konsumen dengan tetap menjunjung etika bisnis.

Pada penelitian ini, penulis memfokuskan untuk membahas tentang bagaimana traksaksi pembayaran catering menggunakan sistem uang muka. Karena, dalam pembayaran catering

\footnotetext{
1 Dosen Fakultas Ekonomi dan Bisnis Islam IAIN Palangka Raya.

2 Dosen Fakultas Ekonomi dan Bisnis Islam IAIN Palangka Raya.

${ }^{3}$ Mahasiswa Magister Ekonomi Syariah Pasca Sarjana IAIN Palangka Raya.
} 
atau pemesan. Sistem uang muka diterapkan agar pemilik catering merasa terjamin bahwa konsumen bersungguh-sungguh terhadap transaksi yang dilakukan.

Uang muka (Down of Payment) dalam bahasa Arab adalah al-'urbūn yang secara bahasa artinya, kata jadi transaksi dalam jual beli. Uang muka adalah sejumlah uang yang dibayarkan terlebih dahulu sebagai tanda jadi pembelian; panjar; persekot. Biasanya dalam transaksi jual beli dipersyaratkan adanya uang muka yang harus dibayar oleh calon pembeli. Uang muka ini berfungsi sebagai refleksi dari kesungguhan calon pembeli dalam transaksi. ${ }^{2}$ Ada perbedaan pendapat para ulama mengenai hukum diperbolehkannya jual beli dengan menggunakan uang muka. Sebagian ulama memperbolehkan dan yang lainnya tidak memperbolehkan jual beli dengan sistem uang muka.

Catering merupakan salah satu bisnis yang menggunakan sistem pembayaran uang muka. Bisnis catering ini telah berkembang secara pesat di Indonesia termasuk juga di Kota Palangka Raya, beberapa diantaranya adalah Catering Aulia dan Catering Hj. Wati dan beberapa catering lainnya. Berdasarkan observasi, Catering Aulia dan Catering Hj. Wati merupakan salah bentuk usaha pelayanan jasa yang menerapkan sistem pemesanan yaitu barang/produk yang dipesan belum dapat diketahui wujudnya secara langsung pada saat akad terjadi. Konsumen dapat memesan barang/produk berdasarkan jenis dan kriteria yang telah ada atau yang diinginkannya. Dan konsumen dapat membayarnya baik secara tunai maupun dengan sistem pembayaran uang muka dalam transaksi pembayarannya.

Sistem pembayaran menggunakan uang muka yang diterapkan di kedua catering ini yaitu tidak ada persentase pasti besarnya uang muka yang harus dibayarkanBerdasarkan latar belakang yang telah diuraikan, maka perumusan permasalah dalam penelitian ini adalah sebagai berikut :Pertama, Bagaimana penerapan uang muka di Catering Aulia dan Catering Hj. Wati di Kota Palangka Raya? Kedua, Bagaimana sistem jual beli dengan menggunakan uang muka perspektif ekonomi Islam?

\section{LANDASAN TEORI}

\section{Konsep Jual Beli dalam Ekonomi Islam}

Secara etimologi, jual beli dapat diartikan sebagai pertukaran sesuatu dengan sesuatu (yang lain). ${ }^{3}$ Jual beli sebagai sarana tolong menolong antara sesama umat manusia mempunyai landasan yang kuat dalam al-Qur'ān dan sunnah Rasulullah SAW. Jual beli mempunyai rukun dan syarat yang harus dipenuhi, sehingga jual beli itu dapat dikatakan sah oleh syara'. Rukun jual beli menurut Jumhur Ulama ada empat, yaitu bāi' (penjual), musytari (pembeli), shighat (ijab dan kabul) dan ma'qud 'alaih (benda atau barang). ${ }^{4}$

Ada beberapa macam jual beli dalam Islam. Salah satu jual beli dalam Islam adalah jual beli'urbūn (persekot), yaitu jual beli yang dilakukan dengan perjanjian pembeli menyerahkan uang seharga barang jika ia setuju jual beli dilaksanakan. Akan tetapi, jika ia membatalkan jual beli, uang yang telah dibayarkan menjadi hibah bagi penjual. Adapula macam-macam jual beli dalam ekonomi Islam antara lain, Ba'i al-Murabahah, Ba'i as-Salam, Ba'i al-Istişnā' dan Ba'i asSharf.

\section{- Uang Muka}

Uang muka (Down of Payment) dalam bahasa Arab adalah al-'urbūn. Uang muka adalah sejumlah uang yang dibayarkan terlebih dahulu sebagai tanda jadi pembelian; panjar; persekot. ${ }^{5}$

\footnotetext{
2Dimyauddin Djuwaini, Pengantar Fiqh Muamalah,Yogyakarta: Pustaka Pelajar, 2010, h. 90.

${ }^{3}$ Buchari Alma dan Donni Juni Priansa, Manajemen Bisnis Syariah, Bandung: Alfabeta, 2014, h. 142.

${ }^{4}$ Rahmat Syafe'i, Fiqih Muamalah untuk UIN,STAIN, PTANIS, dan Umum, Bandung:Pustaka Setia, 2006, h. 76.

${ }_{5}^{5}$ agum Save. M, Kamus Besar Ilmu Pengetahuan. Edisi kedua, cet. V, Jakarta: LPKN, 1997,h.1161.
} 
Uang muka ini berfungsi sebagai refleksi dari kesungguhan calon pembeli dalam transaksi. Terkadang, penjual merasa untuk meminta uang tersebut, agar calon pembeli bersungguhsungguh terhadap transaksi yang dilakukan. Selain itu juga digunakan sebagai buffer atas transaksi yang dilakukan kedua pihak. Uang tersebut dapat dijadikan back-upatas kerugian penjual, jika calon pembeli membatalkan transaksi. ${ }^{6}$

Ulama fiqh berbeda pendapat atas keabsahan transaksi ini, jumhur ulama (kebanyakan) mengatakan bahwa Bāi' 'urbūn merupakan jual beli yang dilarang dan tidak shahih. Namun Wahbah Zuhaili membenarkan praktik pembayaran uang muka ini dalam transaksi jual beli dengan dalil adanya 'urf. ${ }^{7}$ 'Urf ialah apa-apa yang saling diketahui oleh manusia dan diam mempraktekannya, baik perkataan, atau perbuatan, atau meninggalkan. ${ }^{8}$

Penggolongan macam-macam 'ádat atau 'urfitu dapat dilihat dari beberapa segi: ${ }^{9}$

a. Ditinjau dari segi materi yang biasa dilakukan ada dua macam yaitu, 'urf qaulidan 'urffi'li.

b. Dari segi ruang lingkup penggunaannya, 'urf terbagi kepada 'urf umum dan atau 'urf khusus.

c. Dari segi penilaian baik dan buruk, 'ādat atau 'urf itu terbagi kepada 'urf yang shahih dan 'urf yang fasid.

Uang muka sering diaplikasikan dalam praktik ekonomi Islam dan/atau perbankan syariah yaitu dalam pembiayaan murabahah. Uang muka murabahah adalah jumlah yang dibayar oleh pembeli (nasabah) kepada penjual (bank syariah) sebagai bukti komitmen untuk membeli barang dari penjual. ${ }^{10}$

\section{- Catering}

Catering adalah usaha jasa yang memberikan pelayanan dalam penyediaan makanan sesuai dengan kebutuhannya. Penyedia jasa catering banyak ditemui di kota besar maupun kecil. Penyedia jasa catering makin bertambah dari waktu ke waktu, menandakan bahwa bisnis di bidang jasa boga ini sangat menjanjikan. Peningkatan usaha catering memang sangat beralasan selain meningkatnya jumlah penduduk yang juga meningkatkan orang yang membutuhkan pelayanan jasa ini. Selain peningkatan penduduk, dengan perubahan gaya hidup penduduk yang ingin lebih praktis maka makin bertambahlah konsumen bisnis catering ini. ${ }^{11}$

Berdasarkan kebutuhan konsumen ada beberapa jenis catering antara lain: Jasa Catering Pesta, Jasa Catering Rantangan, Jasa Catering Perusahaan/Pabrik, Jasa Catering Trasportasi, Jasa Catering Rumah Sakit, Jasa Catering Khusus dan Jasa Catering Kantoran. ${ }^{12}$

\section{- Konsep Maqāsid as-Syarï’ah}

Secara bahasa Maqāsid as-Syarī’ah terdiri dari dua kata, yakni maqāsid dan syarīah. Maqāsid berarti kesengajaan atau tujuan. Sedangkan syarīah secara bahasa berarti jalan menuju sumber air atau dapat pula dikatakan sebagai jalan ke arah sumber pokok kehidupan. ${ }^{13}$

Di kalangan ulama ushul fiqh, tujuan hukum itu biasa disebut dengan maqāsid as-Syarīah, yaitu tujuan as-Syarīdalam menetapkan hukum. Tujuan hukum tersebut dapat dipahami melalui penelusuran terhadap ayat-ayat al-Qur'ān dan sunnah Rasulullah SAW. Penelusuran yang dilakukan ulama ushul fiqh tersebut menghasilkan kesimpulan, bahwa tujuan as-Syarï'

\footnotetext{
${ }^{6}$ Dimyauddin Djuwaini, Pengantar Fiqh Muamalah... h. 90.

${ }^{7}$ Ibid., h. 91-92.

${ }^{8}$ Nazar Bakry, Fiqh dan Ushul Fiqh, Jakarta: PT. RajaGrafindo Persada, 2003, h. 236.

${ }^{9}$ Amir Syarifuddin, Ushul Fiqh Jilid 2, Jakarta: Logos Wacana Ilmu, 1999, h. 365-368.

${ }^{10}$ Gustani, “Akuntansi Uang Muka Murabahah", Diambil dari: https://gustani.blogspot. co.id/2016/04/akuntansi-uang-mukamurabahah.html (Online pada hari Jum'at, 16 Juni 2017, Pukul 05.35 WIB).

${ }^{11}$ Wulan Ayodya, Business Plan Usaha Kuliner Skala UMKM, Jakarta: PT. Elex Media Komputindo, 2016 , h. 148.

${ }^{12}$ Tri Astuti , "Bisnis Catering", 2010, Diambil dari:http://triastuti1eb21.blogspot.co.id /2010/12/bisnis-catering_03.html (Online pada hari Rabu, 02 November 2016, Pukul 13.01 WIB).

${ }^{13}$ Asafri Jaya Bakri, Konsep Maqashid Syari'ah Menurut Al-Syatibi, Jakarta: PT. RajaGrafindo Persada, 1996, h. 61.
} 
menetapkan hukum adalah untuk kemaslahatan manusia (al-mashlahah), baik di dunia maupun di akhirat. ${ }^{14}$

Tolak ukur untuk menentukan baik buruknya sesuatu yang dilakukan dan yang menjadi tujuan pokok pembinaan hukum itu adalah apa yang menjadi kebutuhan dasar bagi kehidupan manusia. Tuntutan kebutuhan bagi kehidupan manusia itu bertingkat-tingkat. Secara berurutan, peringkat kebutuhan itu adalah primer, sekunder, dan tertier. ${ }^{15}$

a. Kebutuhan Primer/Dharūri. Yaitu sesuatu yang harus ada untuk keberadaan Ada lima hal yang harus ada pada diri manusia sebagai ciri atau kelengkapan kehidupan manusia adalah: agama, jiwa, akal, harta dan keturunan.

b. Kebutuhan Sekunder/Hājiyat. Tujuan tingkat "sekunder" bagi kehidupan manusia ialah sesuatu yang dibutuhkan bagi kehidupan manusia, tetapi tidak mencapai tingkat dharuri.

c. Kebutuhan Tertier/Tahsinniyat. Tujuan tingkat "tertier" adalah sesuatu yang sebaiknya ada untuk memperindah kehidupan.

\section{METODE PENELITIAN}

\section{Pendekatandan Jenis Penelitian}

Penelitian ini menggunakan pendekatan kualitatif deskriptif. Sedangkan jenis penelitian yang digunakan dalam penelitian ini adalah penelitian lapangan.

\section{TeknikPengumpulan Data}

\section{- Observasi}

Pada penelitian ini peneliti melakukan observasi awal ke lokasi penelitian yaitu Catering Aulia dan Catering Hj. Wati di Kota Palangka Raya. Langkah observasi ini penulis lakukan untuk mengetahui mengenai sistem uang muka yang diterapkan oleh kedua catering tersebut.

\section{- Wawancara (Interview)}

Pada penelitian ini peneliti melakukan wawancara dengan subjek-subjek penelitian mengenai penerapan uang muka yanng diterapkan di Catering Aulia dan Catering Hj. Wati.

\section{- Dokumentasi}

Dokumentasi yang terkait dengan penelitian ini seperti Surat Izin Mendirikan Usaha dan Nomor Pokok Wajib Pajak (NPWP).

\section{Teknik Analisis Data}

Beberapa langkah yang ditempuh dalam menganalisa data seperti berikut.

\section{- Collections}

Collections atau pengumpulan data ialah mengumpulkan data sebanyak mungkin mengenai hal-hal yang berkaitan dengan permasalahan dalam penelitian ini.

\section{- Reduction data}

Reduction data atau pengurangan data merupakan analisa data dengan cara menggolongkan, menajamkan, memilih data yang relevan dan tidak relevan untuk digunakan dalam pembahasan.

\footnotetext{
${ }^{14} \mathrm{Abd}$. Rahman Dahlan, Ushul Fiqh, Cet. 2, Jakarta: Amzah, 2011, h. 304.

${ }^{15}$ Amir Syarifuddin, Ushul Fiqh Jilid 2...h.208-214.
} 


\section{- Display data}

Display data atau penyajian data ialah data yang sudah direduksi tersebut disajikan dalam bentuk laporan.

\section{- Verification}

Verification atau penarikan kesimpulan, dimana setelah data semuanya di peroleh kemudian mencari kesimpulan sebagai jawaban dari rumusan masalah.

\section{PENYAJIAN DAN ANALISIS DATA}

\section{Penerapan Uang Muka di Catering Aulia dan Catering Hj. Wati di Kota Palangka Raya}

Berdasarkan hasil wawancara yang telah peneliti lakukan dengan subjek-subjek penelitian diketahui bahwa untuk melakukan pesanan di Catering Aulia dan Catering Hj. Wati menerapkan sistem uang muka dalam pembayarannya dimana pihak konsumen diharuskan untuk membayar sejumlah uang di muka pada saat awal pemesanan.Uang muka dijadikan sebagai tanda jadi atau pengikat antara pihak konsumen dan pihak catering. Dalam sistem pembayarannya Catering Aulia dan Catering Hj. Wati lebih mengutamakan kepada kepercayaan antara kedua belah pihak baik pemilik catering dan konsumen sebagai pemesan catering.

Apabila terjadi pembatalan pesanan baik Catering Aulia maupun Catering $\mathrm{Hj}$. Wati mengembalikan uang muka secara penuh kepada konsumen. Namun, apabila pihak catering telah dirugikan pada saat pembatalan pesanan maka uang muka diambil sebesar kerugian yang ditanggung oleh pihak catering.

Uang muka merupakan salah satu jenis jual beli yang sekarang berkembang di masyarakat. Berkembangnya jual beli dengan menerapkan sistem uang muka ini adalah gambaran dari 'urf atau kebiasaan yang dilakukan masyarakat jika mereka melakukan jual beli pesanan atau kredit. Pada dasarnya segala bentuk muamalah adalah diperbolehkan sampai ada dalil yang melarangnya. Jual beli dengan menggunakan sistem uang muka atau disebut juga dengan Bāi' 'urbūn. Hadis-hadis yang meriwayatkan tentang bāi' 'urbūn kedudukannya adalah lemah. Namun karena bāi' 'urbūn sudah menjadi bagian dari transaksi jual beli dalam perdagangan dewasa ini maka praktik pembayaran uang muka ini dapat dibenarkan dalam transaksi jual beli dengan dalil adanya 'urf.

Kaidah yang sesuai dengan 'urf yaitu: 16

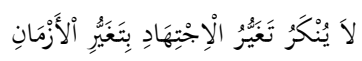

Artinya: Tidak dipungkiri adanya perubahan hukum dengan berubahnya zaman.

Sistem uang muka pun dapat diperbolehkan jika dilakukan atas dasar suka rela tanpa mengandung unsur paksaan antara penjual dan pembeli. Serta tujuan dari diterapkan uang muka ini adalah sebagai simbol tanda jadi antara penjual dan pembeli. Sehingga, diantara kedua belah pihak baik penjual dan pembeli memiliki ikatan dan saling merasa terjamin atas transaksi yang dilakukan. Uang muka juga diterapkan agar meminimalisir terjadinya unsur penipuan dalam transaksi jual beli terutama dalam jual beli pesanan.

\section{Sistem Jual Beli dengan Menggunakan Uang Muka Perspektif Ekonomi Islam}

Islam merupakan panduan bagi manusia untuk bertindak, berinteraksi dan bergaul dengan manusia lainnya. Salah satu bentuk interaksi tersebut adalah dalam bidang ekonomi

\footnotetext{
${ }^{16}$ Rozalinda, Fikih Ekonomi Syariah: Prinsip dan Implementasinya Pada Sektor Keuangan Syariah,Jakarta: PT. RajaGrafindo Persada, 2016, h. 417
} 
(muamalah) yang melibatkan berbagai pihak. Ekonomi seperti jual beli dibolehkan dengan syarat berada pada norma-norma yang telah ditetapkan dalam ajaran Islam. ${ }^{17}$

Dapat dipahami bahwa ekonomi Islam adalah ilmu yang mepelajari segala perilaku manusia dalam memenuhi kebutuhan hidupnya dengan tujuan memperoleh falah, yaitu kesempurnaan dunia dan akhirat dan merupakan konsekuensi logis dari implementasi ajaran Islam secara kaffah dalam aspek ekonomi. Falah dapat terwujud apabila terpenuhi kebutuhankebutuhan hidupmanusia secara seimbang tercipta mashlahah. ${ }^{18}$

Umat Islam dalam berbagai aktivitasnya harus selalu berpegang dengan norma-norma ilahiyah, begitu juga dalam muamalah. Kewajiban berpegang pada norma ilahiyah adalah sebagai upaya untuk melindungi hak masing-masing pihak dalam bermuamalah. Secara singkat, prinsip-prinsip muamalah yang telah diatur dalam hukum Islam tertuang dan terangkum dalam kaidah dan prinsip-prinsip dasar fiqh muamalah. Kaidah paling dasar dan paling utama yang menjadi landasan kegiatan muamalah adalah kaidah yang sangat terkenal dan disepakati oleh ulama empat mazhab. ${ }^{19}$

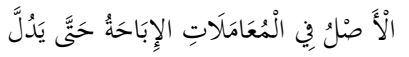

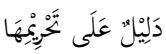

Artinya: Pada dasarnya, semua bentuk muamalah boleh dilakukan, kecuali ada dalil yang mengharamkannya. ${ }^{20}$

Berdasarkan pemaparan di atas, maka pada dasarnya manusia diberi kebebasan untuk mengembangkan model muamalah. Implikasi dari kebebasan dalam hal muamalah adalah kebebasan dalam inovasi pengembangan produk. Meskipun ada legitimasi dalam pengembangan muamalah, pengembangan model transaksi dan produk dalam konteks ekonomi Islam tetap harus mempunyai landasan dan dasar hukum yang jelas dari perspektif fiqh. Landasan hukum ini diperlukan agar pengembangan ekonomi Islam dengan segala produknya tidak berkembang liar dan keluar dari koridor Islam atau bahkan bertentangan dengan prinsip-prinsip ekonomi syariah yang kental dengan nuansa moral ilahiyah. ${ }^{21}$

Transaksi jual beli merupakan suatu bagian yang tidak dapat terpisahkan dalam kehidupan manusia. Untuk mendapatkan semua kebutuhan sehari-hari semuanya diperoleh melalui perdagangan (jual beli). Jual beli dalam Islam kaitannya tidak hanya untuk kepentingan duniawi saja. Karena itu, Allah SWT. telah mengatur dengan sempurna aturan-aturan yang harus diterapkan dalam melakukan transaksi jual beli. Salah satu yang telah menjadi kebiasaan masyarakat dalam melakukan transaksi jual beli adalah dengan menggunakan sistem uang muka atau di masyarakat sering disebut dengan sistem panjar.Uang muka adalah sejumlah uang yang dibayarkan terlebih dahulu sebagai tanda jadi atau pengikat yang menyatakan bahwa pembelian itu jadi dilaksanakan dan pada umumnya jika ternyata pembeli membatalkan maka panjar itu tidak dapat diminta kembali.

Ulama fiqh berbeda pendapat atas keabsahan transaksi ini, jumhur ulama mengatakan bahwa bāi' 'urbūn merupakan jual beli yang dilarang dan tidak shahih. Menurut madzhab

\footnotetext{
${ }^{17}$ Havis Aravik, Ekonomi Islam: Konsep, Teori dan Aplikasi serta Pandangan Pemikir Ekonomi Islam dari Abu Ubaid sampai Al-Maududi, Malang: Empat Dua, 2016, h. 1.

${ }^{18}$ Havis Aravik, Ekonomi Islam: Konsep, Teori dan Aplikasi serta Pandangan Pemikir Ekonomi Islam dari Abu Ubaid sampai Al-Maududi, h.4.

${ }^{19}$ Imam Mustofa, Fiqih Mu'amalah Kontemporer, Jakarta: PT. RajaGrafindo Persada, 2016, h. 9.

${ }^{20}$ Syarif Hidayatullah, Qawa'id Fiqiyyah dan Penerapannya dalam Transaksi Keuangan Syariah Kontemporer (Muamalat, Maliyyah Islamiyyah, Mu’ashirah), Jakarta: Gramata Publishing, 2012h. 136.

${ }^{21}$ Imam Mustofa, Fiqih Mu'amalah Kontemporer...h. 10-11.
} 
Hanafiyah, merupakan jual beli yang fasid (rusak), dan dianggap batil oleh sebagian ulama lainnya. Hal ini dilandasi atas hadis Rasulullah SAW, kedudukan dari hadis ini dha'if (lemah). ${ }^{22}$

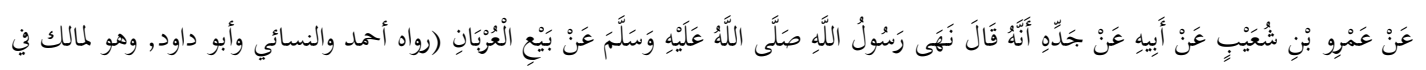

Artinya: Dari Amru bin Syu'aib, dari ayahnya dari kakeknya, ia berkata bahwa Nabi SAW melarang jual beli 'urbūn.' (HR. Ahmad, Nasa'i, Abu Daud dan Hadis ini diriwayatkan juga oleh Imam Malik dalam Al-Muwatha').

Selain itu juga disebabkan bahwa dalam bāi' 'urbūn terdapat gharar, risiko dan memakan harta orang lain tanpa adanya kompensasi. Menurut Imam Ahmad bin Hambal, bāi' 'urbūn diperbolehkan dengan dalil hadis dari Abd ar Razzaq dan hadis Zaid bin Aslam, kedudukan dari hadis ini lemah: "Bahwasanya Rasulullah SAW menghalalkan uang muka dalam jual beli." 23

Imam Ahmad menyatakan bahwa hadis yang meriwayatkan tentang bāi' 'urbūn kedudukannya adalah lemah. Namun demikian, bāi' 'urbūn sudah menjadi bagian dari transaksi jual beli dalam perdagangan atau perniagaan dewasa ini. Pembayaran uang muka tersebut dijadikan sebagai buffer ${ }^{24}$ atas kemungkinan kerugian yang diderita oleh penjual, jika transaksi batal dilakukan. Namun Wahbah Zuhaili membenarkan praktik pembayaran uang muka ini dalam transaksi jual beli dengan dalil adanya 'urf. 25

'Urf atau kebiasaan telah berkembang di tengah masyarakat begitupula di dalam bidang ekonomi Islam seperti halnya jual beli. Di mana akad yang dilakukan masyarakat biasanya berdasarkan pada kebiasaan mereka dalam melakukan transaksi jual beli. 'Urf dapat mengalami perkembangan dan perubahan setiap waktu. 'Urf yang pada awalnya dianggap tidak dapat diterapkan sebagai hukum dapat dijadikan hukum di kemudian waktu jika ternyata banyak kemashlahatan yang ada jika 'urf tersebut dijadikan hukum.

Uang muka sering diaplikasikan dalam praktik ekonomi Islam dan/ atau perbankan syariah yaitu dalam pembiayaan murabahah. Salah satu skim yang paling popular digunakan oleh perbankan syariah adalah skim jual beli murabahah. Pembayaran bisa dilakukan secara tunai atau bisa dilakukan di kemudian hari yang disepakati bersama. Oleh karena itu, murabahah tidak dengan sendirinya mengandung konsep pembayaran tertunda (deferred payment). ${ }^{26}$

Pembiayaan murabahah dapat dilakukan secara pemesanan dengan cara janji untuk melakukan pembelian. Pembeli dibolehkan meminta pemesan membayar uang muka saat menandatangani kesepakatan awal pemesanan. Untuk menjaga pemesan tidak main-main dengan pesanan maka diperbolehkan meminta jaminan. ${ }^{27}$

Berkenaan dengan produk murabahah yang diaplikasikan pada bank syariah yang termasuk masalah uang muka Dewan Syariah Nasional (DSN) MUI telah menetapkan dalam fatwanya No. 04/DSN-MUI/IV/2000 tentang hukum dibolehkannya murabahah dan aturanaturan pelaksanaannya. Dalam fatwanya No. 13/DSN-MUI/IX/2000 tentang hukum dibolehkannya meminta uang muka dalam murabahah oleh perbankan syariah dan dalam fatwanya No. 16/DSN-MUI/IX/2000 tentang hukum boleh diskon dalam murabahah. ${ }^{28}$

\footnotetext{
${ }^{22}$ Dimyauddin Djuwaini, Pengantar Fiqh Muamalah... h. 91.

${ }^{23}$ Ibid.

${ }^{24}$ Jaminan;agunan.

${ }^{25}$ Dimyauddin Djuwaini, Pengantar Fiqh Muamalah... h. 91-92.

${ }^{26}$ Ascarya, Akad dan Produk Bank Syariah, Jakarta: PT.RajaGrafindo Persada, 2011, h. 81-82.

${ }^{27}$ Rozalinda, Fikih Ekonomi Syariah: Prinsip dan Implementasinya Pada Sektor Keuangan Syariah...h. 89-90.

${ }^{28}$ Syarif Hidayatullah, Qawa'id Fiqiyyah dan Penerapannya dalam Transaksi Keuangan Syariah Kontemporer (Muamalat, Maliyyah Islamiyyah, Mu'ashirah), h. 143.
} 
Berdasarkan fatwa DSN-MUI No. 13/DSN-MUI/IX/2000 tentang hukum dibolehkannya meminta uang muka dalam murabahah oleh perbankan syariah terdapat beberapa ketentuan umum tentang uang muka, antara lain: ${ }^{29}$

a. Dalam akad pembiayaan murabahah, Lembaga Keuangan Syari'ah (LKS) dibolehkan untuk meminta uang muka apabila kedua belah pihak bersepakat.

b. Besar jumlah uang muka ditentukan berdasarkan kesepakatan.

c. Jika nasabah membatalkan akad murabahah, nasabah harus memberikan ganti rugi kepada LKS dari uang muka tersebut.

d. Jika jumlah uang muka lebih kecil dari kerugian, LKS dapat meminta tambahan kepada nasabah.

e. Jika jumlah uang muka lebih besar dari kerugian, LKS harus mengembalikan kelebihannya kepada nasabah.

Berdasarkan paragraf di atas maka menurut hemat penulis bahwa penerapan uang muka diperbolehkan dalam ekonomi Islam karena telah lama di aplikasikan dalam praktik sehari-hari baik dalam bentuk jual beli maupun dalam aktivitas perbankan syariah. Penerapan uang muka diperbolehkan karena dilihat dari segi kemashlahatannya. Penerapan uang muka ini jika dilihat dari segi materi yang biasa dilakukan termasuk ke dalam 'urf fi'li, sedangkan dilihat dari segi penilaian baik dan buruk penerapan uang muka termasuk ke dalam 'urf shahih.

Penerapan uang muka di Catering Aulia dan Catering Hj. Wati perspektif ekonomi Islam telah sesuai jika dilihat dari isi fatwa DSN-MUI No. 13/DSN-MUI/IX/2000. Besaran uang muka ditentukan berdasarkan kesepakatan dari kedua belah pihak yaitu pemilik catering dan pengguna jasa catering. Apabila di tengah transaksi terjadi pembatalan pesanan catering maka uang muka dikembalikan sepenuhnya jika pihak catering tidak ada mengalami kerugian. Namun, jika pihak catering telah mengalami kerugian akibat pembatalan pesanan maka uang muka dapat diambil sebesar kerugian itu. Jika masih terdapat kelebihan uang muka setelah digantinya kerugian maka pihak catering wajib mengembalikan sisa uang muka tersebut.

\section{PENUTUP}

Sistem pembayaran uang muka yang diterapkan di Catering Aulia dan Catering $\mathrm{Hj}$. Wati di Kota Palangka Raya pada prakteknya tidak ada besaran uang muka yang ditetapkan kepada konsumen. Apabila di tengah transaksi terjadi pembatalan pesanan catering maka uang muka dikembalikan sepenuhnya jika pihak catering tidak ada mengalami kerugian. Namun, jika pihak catering telah mengalami kerugian maka uang muka dapat diambil sebesar kerugian itu.

Penerapan uang muka di Catering Aulia dan Catering $\mathrm{Hj}$. Wati telah sesuai dengan ekonomi Islam yang telah diatur dalam fatwa DSN-MUI. Penerapan uang muka dari segi materi yang biasa dilakukan termasuk ke dalam 'urf fi'li, sedangkan dari segi penilaian baik dan buruk termasuk ke dalam 'urfshahih.

\section{DAFTAR PUSTAKA}

Alma, Buchari dan Donni Juni Priansa, Manajemen Bisnis Syariah, Bandung: Alfabeta, 2014.

Aravik, Havis, Ekonomi Islam: Konsep, Teori dan Aplikasi serta Pandangan Pemikir Ekonomi Islam dari Abu Ubaid sampai Al-Maududi, Malang: Empat Dua, 2016.

Ascarya, Akad dan Produk Bank Syariah, Jakarta: PT.RajaGrafindo Persada, 2011.

${ }^{29}$ ___ “Fatwa DSN-MUI” Diambil dari: http://www.dsnmui.or.id (Online pada hari Kamis, 04 Mei 2017, Pukul 08.00 WIB). 
Ayodya, Wulan, Business Plan Usaha Kuliner Skala UMKM, Jakarta: PT. Elex Media Komputindo, 2016.

Bakri, Asafri Jaya, Konsep Maqashid Syari'ah Menurut Al-Syatibi, Jakarta: PT. RajaGrafindo Persada, 1996.

Bakry, Nazar, Fiqh dan Ushul Fiqh, Jakarta: PT. RajaGrafindo Persada, 2003.

Dahlan, Abd. Rahman, Ushul Fiqh, Cet. 2, Jakarta: Amzah, 2011.

Djuwaini, Dimyauddin,Pengantar Fiqh Muamalah,Yogyakarta: Pustaka Pelajar, 2010.

Hidayatullah, Syarif, Qawa'id Fiqiyyah dan Penerapannya dalam Transaksi Keuangan Syariah Kontemporer (Muamalat, Maliyyah Islamiyyah, Mu'ashirah), Jakarta: Gramata Publishing, 2012.

Mustofa, Imam, Fiqih Mu'amalah Kontemporer, Jakarta: PT. RajaGrafindo Persada, 2016.

Rozalinda, Fikih Ekonomi Syariah: Prinsip dan Implementasinya Pada Sektor Keuangan Syariah, Jakarta: PT. RajaGrafindo Persada, 2016.

Save, Dagum M, Kamus Besar Ilmu Pengetahuan. Edisi kedua, cet. V, Jakarta: LPKN, 1997.

Syafe'i, Rahmat, Fiqih Muamalah untuk UIN,STAIN, PTANIS, dan Umum, Bandung:Pustaka Setia, 2006.

Syarifuddin, Amir, Ushul Fiqh Jilid 2, Jakarta: Logos Wacana Ilmu, 1999.

\section{Internet}

Tri Astuti, "Bisnis Catering", 2010, Diambil dari: http://triastuti1eb21.blogspot.co.id /2010/12/bisnis-catering_03.html (Online pada hari Rabu, 02 November 2016, Pukul 13.01 WIB). "Fatwa DSN-MUI" Diambil dari: http://www.dsnmui.or.id (Online pada hari Kamis, 04 Mei 2017, Pukul 08.00 WIB).

Gustani, "Akuntansi Uang Muka Murabahah", Diambil dari: https://gustani.blogspot.co.id/2016/04/akuntansi-uang-muka-murabahah.html (Online pada hari Jum’at, 16 Juni 2017, Pukul 05.35 WIB). 